\title{
FAILURE TO DEMONSTRATE A RÔLE FOR THE ACUTE RELEASE OF PROLACTIN AT OESTRUS IN THE EWE
}

\author{
B. P. LOUW, ${ }^{*}$ A. W. LISHMAN, W. A. BOTHA* AND \\ J. P. BAUMGARTNER \\ Department of Animal Science, University of Natal, \\ Pietermaritzburg, South Africa
}

(Received 8th March 1974)

Prolactin is readily secreted before and during oestrus in ewes (Kann, 1971; Cumming, Brown, Goding, Bryant \& Greenwood, 1972) and Denamur, Martinet \& Short (1973) indicated that this hormone has a luteotrophic effect. Although these findings suggest that prolactin contributes to normal reproduction in ewes, the physiological rôle of the prolactin|surge at oestrus has as yet not been elucidated.

In the rat and mouse, a surge of prolactin on the afternoon of pro-oestrus promotes luteolysis of corpora lutea (Malven \& Sawyer, 1966; Grandison \& Meites, 1972). Such an effect appears unlikely in sheep since luteal regression in this species commences several days before the onset of oestrus (Deane, Hay, Moor, Rowson \& Short, 1966).

Prolactin is also rapidly released into the circulation in response to the milking stimulus in lactating ewes (Fell, Beck, Brown, Catt, Cumming \& Goding, 1972) and it has been suggested that the secretion of large quantities of this hormone contributes to the manifestation of lactation anoestrus in sheep (Hunter, 1968) and cattle (Symington, 1969). In humans, Tyson, Friesen \& Anderson (1972) proposed that prolactin secretion during lactation decreases the ovarian response to circulating gonadotrophins, and consequently reduces the possibility of ovulation occurring during the lactation period.

In order to determine whether a deficiency of prolactin would affect the oestrous cycle of the ewe, the release of prolactin from the pituitary was suppressed with ergocornine hydrogen maleinate (EC). In the first experiment, thirteen Merino ewes were selected from a large flock on the basis of spontaneous synchronization of oestrus. Commencing at 18.00 hours on the day before the expected onset of oestrus, ten ewes were injected subcutaneously with $1.25 \mathrm{mg} \mathrm{EC}$ and the injections were repeated at intervals of $6 \mathrm{hr}$ until $30 \mathrm{hr}$ after oestrus was first detected. Using the same schedule, the remaining three ewes were injected with $1.0 \mathrm{ml}$ of the suspension vehicle $(4.0 \%$ ethanol in $0.9 \%$ saline) and served as controls. Immediately after the first EC or salineethanol injection, a sample of blood $(5 \mathrm{ml})$ was drawn through a silastic can-

\footnotetext{
* Present address: College of Agriculture and Research Institute, Private Bag X 9059, Pietermaritzburg, South Africa.
} 
nula inserted into the jugular vein of each ewe. Sampling was repeated at intervals of $4 \mathrm{hr}$ until the onset of oestrus, after which the samples were obtained at 2-hr intervals for a period of $36 \mathrm{hr}$. Plasma prolactin and LH were assayed by the double-antibody techniques of Davis, Reichert \& Niswender (1971) and Niswender, Reichert, Midgley \& Nalbandov (1969), respectively, using antisera raised in this laboratory (Lishman, Stielau, Dreosti \& Stewart, 1973).

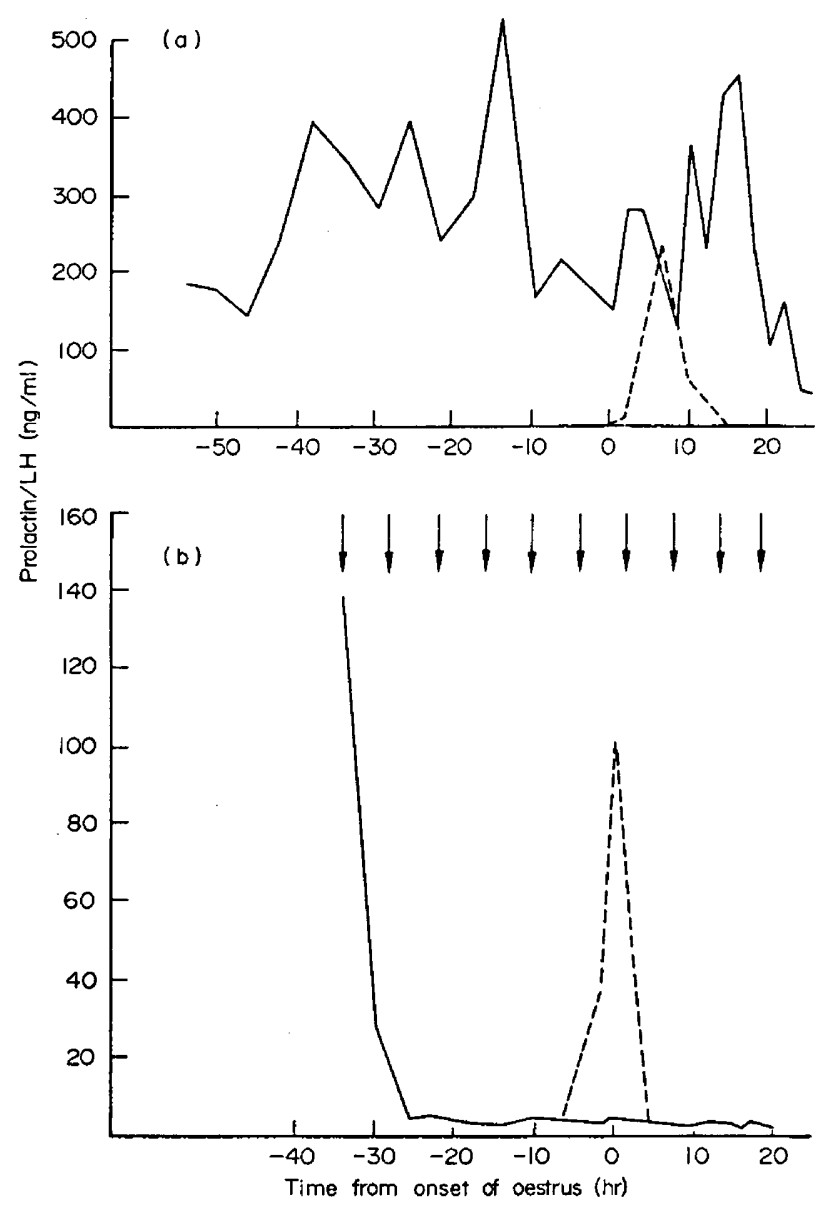

TexT-Fig. 1. Plasma levels of prolactin (-) and LH (- - - ) at oestrus in (a) an untreated control ewe and (b) a ewe in which prolactin release was blocked by ergocornine hydrogen maleinate (EC). $\downarrow$ Denotes injection of $1.25 \mathrm{mg} \mathrm{EC}$.

The patterns of prolactin and LH secretion in a randomly selected ewe treated with EC, and in a control ewe, are illustrated in Text-fig 1 . It is evident that the irregular surges of prolactin in the control ewe (Text-fig. 1a) were effectively inhibited in the EG-treated ewe (Text-fig. 1b). In the latter category, plasma levels of prolactin as low as 1 to $5 \mathrm{ng} / \mathrm{ml}$ were obtained 8 to $12 \mathrm{hr}$ after the first EC injection. These results are in accordance with the reported inhibitory influence of ergot derivatives on prolactin secretion in rats (Wuttke, 
Cassel \& Meites, 1971), man (del Pozo, Brun del Re, Varga \& Friesen, 1972) and goats (Hart, 1973).

The secretion of $\mathrm{LH}$ in the ewes was evidently not influenced by treatment with EC. The surge lasted for $10.9 \pm 0.4 \mathrm{hr}$ in the treated and $11.1 \pm 1.0 \mathrm{hr}$ in the control animals. The maximum concentration of this hormone varied between 106 and $276 \mathrm{ng} / \mathrm{ml}$ (control ewes) and 65 to $250 \mathrm{ng} / \mathrm{ml}$ (EC-treated ewes).

It appeared that the onset of oestrus in the experimental animals was delayed by approximately $24 \mathrm{hr}$, but this delay is probably due to the stress imposed by frequent sample collection and observations for oestrus. Doney, Gunn \& Griffiths (1973) have noted a similar effect in ewes exposed to stress during the last 4 days of the oestrous cycle. Inhibition of prolactin release at oestrus did not influence the length of the subsequent oestrous cycle since the EGtreated ewes again exhibited overt oestrus $16 \cdot 8 \pm 0 \cdot 31$ days later.

The results obtained in the first experiment suggested that when EC treatment was initiated, the prolactin surge had already commenced. Consequently a second experiment was conducted in which prolactin secretion in seven ewes was suppressed for a period which would include two successive periods of oestrus. If prolactin is luteotrophic, as suggested by Denamur et al. (1973), a deficiency throughout the cycle could be expected to reduce the life-span of the corpus luteum.

Injections of EG were given at 16.00 hours on Day 15 of the oestrous cycle (Cycle 1) and repeated at intervals of $8 \mathrm{hr}$ throughout the following cycle (Cycle 2) and until Day 2 of Cycle 3. The day of oestrus was regarded as Day 1.

To minimize stress, plasma was obtained on only one occasion during the experiment, a few minutes before an EG injection. The prolactin content of the plasma was found to vary from 0.5 to $2.3 \mathrm{ng} / \mathrm{ml}$ in the seven ewes, indicating that release of prolactin was inhibited.

Sexually active vasectomized rams were placed with the ewes at intervals of $8 \mathrm{hr}$ throughout the experiment. Ovarian examination following laparotomy was conducted on Day 4 of Cycle 3, i.e. approximately 4 days after the onset of oestrus, and approximately 2 days after the last EG injection. Thereafter, observations for oestrus were continued for a further 30 days.

The suppression of prolactin release in the ewes for a period of 20 days did not influence the occurrence of oestrus and ovulation. At least one normal corpus luteum was observed in the treated ewes when laparotomies were conducted. Two of the treated ewes apparently underwent silent ovulations shortly after the commencement of the experiment. Heat was first observed in these animals approximately 35 days after the oestrous period which occurred before the start of this trial.

The results obtained in the present study suggest that the large quantity of prolactin which is released before and during oestrus in ewes is not essential for the ovarian changes which occur at this stage of the oestrous cycle. The possibility that the small amounts of prolactin which were released were sufficient to maintain ovarian function cannot be excluded. Cumming et al. (1972) have suggested that the prolactin which is secreted during oestrus in ewes may be stored in the follicle and subsequently influences the development of the corpus luteum. Although no definite conclusion regarding this hypothesis, 
or that concerning the luteotrophic properties of prolactin, can be made from the results obtained, it is apparent that oestrus, ovulation and luteal maintenance during the oestrous cycle are not dependent on the acute release of prolactin at oestrus. The rôle of this hormone in conception, however, has apparently not been investigated.

The authors are indebted to Dr H. Lantz, Sandoz Ltd, Basle, Switzerland, for the kind gift of ergocornine hydrogen maleinate.

\section{REFERENCES}

Gumming, I. A., Brown, J. M., Goding, J. R., Bryant, G. D. \& Greenwood, F. G. (1972) Secretion of prolactin and luteinizing hormone at oestrus in the ewe. . Endocr. 54, 207.

Davis, S. L., Reichert, L. E. \& Niswender, G. D. (1971) Serum levels of prolactin in sheep as measured by radioimmunoassay. Biol. Reprod. 4, 145.

Deane, H. W., Hay, M. F., Moor, R. M., Rowson, L. E. A. \& Short, R. V. (1966) The corpus luteum of the sheep: relationship between morphology and function during the oestrous cycle. Acta endocr., Copenh. 51, 245.

del Pozo, E., Brun del Re, R., Varga, L. \& Frizsen, H. (1972) The inhibition of prolactin secretion in man by CB-154 (2-Br- $\alpha$-ergocryptine). 7. clin. Endocr. Metab. 35, 768.

Denamur, R., Martinet, J. \& Short, R. V. (1973) Pituitary control of the ovine corpus luteum. 7. Reprod. Fert. 32, 207.

Doney, J. M., GunN, R. G. \& GRiffiths, J. G. (1973) The effect of premating stress on the onset of oestrus and ovulation rate in Scottish Blackface ewes. 7. Reprod. Fert. 35, 381.

Fel., L. R., Beck, G., Brown, J. M., Catt, K. J., Gumming, I. A. \& Goding, J. R. (1972) Solid-phase radioimmunoassay of ovine prolactin in antibody-coated tubes. Prolactin secretion during estradiol treatment, at parturition, and during milking. Endocrinology, 91, 1329.

Grandison, L. \& Meites, J. (1972) Luteolytic action of prolactin during the oestrous cycle of the mouse. Proc. Soc. exp. Biol. Med. 140, 323.

HART, I. C. (1973) Effect of 2-Bromo- $\alpha$-ergocryptine on milk yield and the level of prolactin and growth hormone in the blood of the goat at milking. 7. Endocr. 57, 179.

Hunter, G. L. (1968) Increasing the frequency of pregnancy in sheep. I. Some factors affecting rebreeding during the post-partum period. Anim. Breed. Abstr. 36, 347.

KanN, G. (1971) Variations des concentrations plasmatiques de l'hormone lutéinisante et de la prolactine au cours du cycle oestrien de la brebis. C. r. hebd. Séanc. Acad. Sci., Paris, 272, 2934.

Lishman, A. W., Stirlau, W. J., Dreosti, I. E. \& Stewart, A. M. (1973) Radioimmunological evaluation of rabbit anti-sera to ovine luteinizing hormone. S. Afr. J. Anim. Sci. 3, 67.

Malven, P. V. \& SAWYeR, C. H. (1966) A luteolytic action of prolactin in hypophysectomized rats. Endocrinology, 79, 268.

Niswender, G. D., Reichert, L. E., Midgley, A. R. \& Nalbandov, A. V. (1969) Radioimmunoassay for bovine and ovine luteinizing hormone. Endocrinology, 84, 1166.

Sxmmgton, R. B. (1969) Factors affecting postpartum fertility in cattle with special emphasis on the hormonal aspects of the problem in ranch cows in Southern Africa. Proc. S. Afr. Soc. Anim. Prod. $8,29$.

Tyson, J. E., Friesen, H. G. \& Anderson, M. S. (1972) Human lactational and ovarian response to endogenous prolactin release. Science, $\mathcal{N} . r .177,897$.

Wuttke, W., Cassel, E. \& Mertes, J. (1971) Effects of ergocornine on serum prolactin and LH, and on hypothalmic content of PIF and LRF. Endocrinology, 88, 737. 